\title{
INDIAN JOURNAL OF SCIENCE AND TECHNOLOGY
}

\section{RESEARCH ARTICLE}

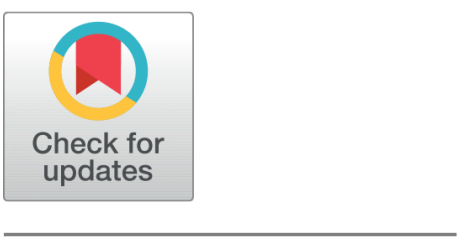

G OPEN ACCESS

Received: 14.09.2020

Accepted: 25.11 .2020

Published: 03.12.2020

Citation: Malik S, Tyagi HK (2020) A study of parent's opinion on online teaching in Delhi-NCR schools. Indian Journal of Science and Technology 13(42): 4351-4363. https ://doi.org/10.17485/IJST/v13i42.1664

* Corresponding author.

seemacpd@gmail.com

Funding: None

Competing Interests: None

Copyright: () 2020 Malik \& Tyagi.

This is an open access article distributed under the terms of the Creative Commons Attribution License, which permits unrestricted use, distribution, and reproduction in any medium, provided the original author and source are credited.

Published By Indian Society for Education and Environment (iSee)

ISSN

Print: 0974-6846

Electronic: 0974-5645

\section{A study of parent's opinion on online teaching in Delhi-NCR schools}

\author{
Seema Malik ${ }^{1 *}$, Harish Kumar Tyagi ${ }^{2}$ \\ 1 Principal, Salwan Public School, Mayur Vihar, New Delhi, India \\ 2 Head, Amity Institute of Behavioural and Allied Science, Amity University, Uttar Pradesh, \\ India
}

\section{Abstract}

Objectives: To explore the challenges parents face when their children study online. Their views and opinions on the efficacy of the online learning program and the attributes of virtual classes are sought in the study. Methods: A survey study was conducted with an online questionnaire administered to more than 2000 parents of pre primary and primary classes from ten public schools of Delhi National Capital Region. Findings: More than $75 \%$ of the parents surveyed are satisfied with the online classes taking place and believed that it is working for them. $41 \%$ of the parents are of the opinion that teaching methodology is the most important factor enhancing the teaching-learning process in virtual mode for the parents. $29 \%$ of the parents believe that personalised attention given to the children can improve the system. These findings help in strengthening the process of online teaching. Novelty: In the recent months a lot of research has been happening in India on the feasibility and efficacy of the online classes owing to the closure of the school after the outbreak of the pandemic. However, most of this research does not take into account the digital divide the parents face. The current study addresses this gap and looks at the online teaching-learning process from the parents' point of view, which can assist the policy makers.

Keywords: Online teaching; parent's opinion; parental intervention; primary classes

\section{Introduction}

Education has been badly hit due to the outbreak of corona pandemic with millions of students stranded at home, staring at the screens and receiving instruction passively ${ }^{(1)}$. Covid-19 has caused huge disruption with tough challenges for the entire education system across the world. Since Indian teachers and students are habituated to everyday meetings and interactions carrying out the teaching and learning activities in classroom ${ }^{(2)}$, it is particularly difficult to engage young children. Parents of pre primary and primary classes 
try to drag the toddlers and the young kids back to the computer screens, trying to get them interested in what's happening ${ }^{(3)}$. Many feel exasperated, thinking that when kids don't even understand half of the activities in real classrooms, how will computer screen make any sense to them. They continue to get the kids to sit for the virtual classes to get value for the fee paid. Some parents believe that what happens during these classes is potentially more destructive than constructive ${ }^{(4)}$. Conditions in the government run schools, even in cities are likely to be worse where neither the school nor the students can afford the luxury of e-classes. Across the board, parents are of the opinion that online classes can never make up for the real classroom experience ${ }^{(5)}$. Young students' engagement particularly depends on their willingness, need and desire to participate in the learning process ${ }^{(6)}$.

School leaders think that their responsibility is to take classes to every student sitting at home through virtual devices but even they contend that with these classes, all around holistic development of the student can not be achieved. A typical report card generated from such cases does not include assessment of communication skills, vocabulary, critical thinking and scientific aptitude. If all of this was not demoralising enough, parents also are not on the side of the schools. They have numerous grievances about online teaching, both structure and methodology. Many refuse to pay the fees at all and most think that they do not receive enough value for money. They are of the opinion that online classes should be regulated in terms of the number of hours of screen time each day to give balance to study and play. Many studies have been conducted recently by schools and NGO's but there is a lack of favourable opinion from the parents' side who are an important stakeholders in the learning system, more so, when it is happening from the home. The current study focuses on the views of parents of pre-primary and primary classes taking place in virtual mode since they control the learning environment at home and support setting up of a physical space intended for learning to encourage the children to study seamlessly.

Recently, parents have vehemently opposed the Ministry of Home Affairs suggestion that schools should be opened now. An online petition on change.org has garnered more than two lakhs signatures, urging the government not to start schools until there are "zero COVID cases", describing the idea of restarting school as "playing with fire". An empirical study conducted by ${ }^{(7)}$ on parents' and students' attitudes towards tablet integration in schools found that parents expressed greater concern over potential negative effects of ICT usage in education than their children. Parents also emphasise potential threats to academic performance ${ }^{(8)}$ by overuse of technology. Failure to recognise parental concerns has hindered the progress of ICT use on a global scale in schools. Their attitudes and perspectives are necessary to be understood for a holistic knowledge of online teaching. The pandemic has imposed an additional role on the parents: that of being a supervisor to their children while they attend the classes, particularly at primary level. A study conducted by ${ }^{(9)}$ shows that parents feel frustrated at helping their young children attending and focusing on the classes in virtual mode. In the present study, at least $70 \%$ of the parents talk about the negative impact of virtual teaching on the children's education. However, in spite of these difficulties, $68.35 \%$ parents do not want the children to return to the school till the covid situation is under control.

The Covid-19 pandemic has put severe restrictions on people's behaviour worldwide ${ }^{(10)}$, which has caused farreaching ramifications on students. With most schools shut down, education has shifted to online mode which has placed a notable burden on all school children's parents throughout the world ${ }^{(11)}{ }^{(12)}$ has estimated that 193 countries have implemented national school closures, affecting 1.57 billion children and young people, roughly $91 \%$ of the global student population. Although this review questions the effectiveness of school closure, currently the schools remain closed globally. Some anecdotal reports on how schools are coping with the situation have been published but there is no scientific report on how parents are handling the present situation with respect to online education. Despite the long existence of distance education, its many online variants and growing popularity ${ }^{(13)}$, this educational method still remains only a supplement to the formal schooling. Although the current generation of students was born in the age of digital media with high potential in learning multiple intelligence approach ${ }^{(14)}$, this can not be said for their parents. It is important to understand the opinion of all stakeholders, particularly the parents to create systematic mapping of possibilities of online teaching.

One of the biggest challenges faced by parents today is how to maximise the benefits and minimise the risks of internet use among young children and teenagers. Effective parental mediation is one of the important actions for 
promoting children's safe and responsible use of internet ${ }^{(15)}$ which affects the online education prevailing today. A research by ${ }^{(16)}$ has found that indiscriminate use of computers leads to distancing between family members. Adolescence is a period when social relationships of the children expand to build enduring relationships ${ }^{(17)}$. Parental mediation plays an important role in this process at this stage since they may limit the child's amount of time spent on digital devices or set some rules regarding the time spent on internet as well as the placing some websites under ban for the children. It is not surprising then, that many students complain of noise and distraction in the studying environment. Thus, parents' own attitude, knowledge and experience of internet use affect their perception of the virtual classes which are now the de-rigueur. Besides, the availability of technology for the vulnerable section of society is limited ${ }^{(18)}$.

\section{Methods}

The survey was conducted for ten schools of Delhi-NCR region, focusing only on primary classes. The total number of parents in this category was 5119. The survey questionnaire was sent to all the parents, requesting them to fill it for the purpose of assisting the schools to improve online education system. It was done on voluntary basis and out of approximately 5199 parents, 2032 responded within a week, making it a 40\% return of the questionnaire. It was administered through google classroom on which the students were taking online classes. As it was a voluntary survey, only those parents responded who wanted to participate in the study. To keep up with the ethics of taking survey study, it remained anonymous and parents were neither asked to write their names nor email id. They also didn't have to write the child's name and class since the teachers collected the responses which came on their google classroom platform. Utmost care was taken neither to send a reminder to the parents nor were they coaxed through the child studying in the respective class. Data was collected on google form and then analysed through graphical representation with the help of percentage for each category/question asked.

\section{Survey findings}

\section{Results from the survey for classes Nursery to II}

Around $76 \%$ of the parents think that their children are engaged with the online classes and approximately $75 \%$ believe that the online program is working for them, showing their satisfaction with the current educational setting. However, $55 \%$ of the respondents opine that the duration of the classes should only be one hour with about $36.5 \%$ saying that they prefer a duration of two hours for the class. Clearly, parents are willing to send their children for three to four hours in the regular school where they also spend time playing in open spaces and interacting with peers in the class. However, they prefer to limit the screen time for their children. Teaching method is the most important factor to $41.7 \%$ of the parents for enhancing the teaching-learning process, with around $30 \%$ saying that personalised attention can improve the process. Personalised learning experience and experiential learning go a long way in making learning effective for such young students since they lead to a deeper level of understanding. So far as the ill-effects of online classes on children's health, more than $74 \%$ do not think this to be true and $76 \%$ agree or strongly agree with the need of online classes in the current scenario with the caveat that duration of online classes must be reduced. 
DO YOU FEEL CONNECTED/ ENGAGED IN ONLINE CLASSES?

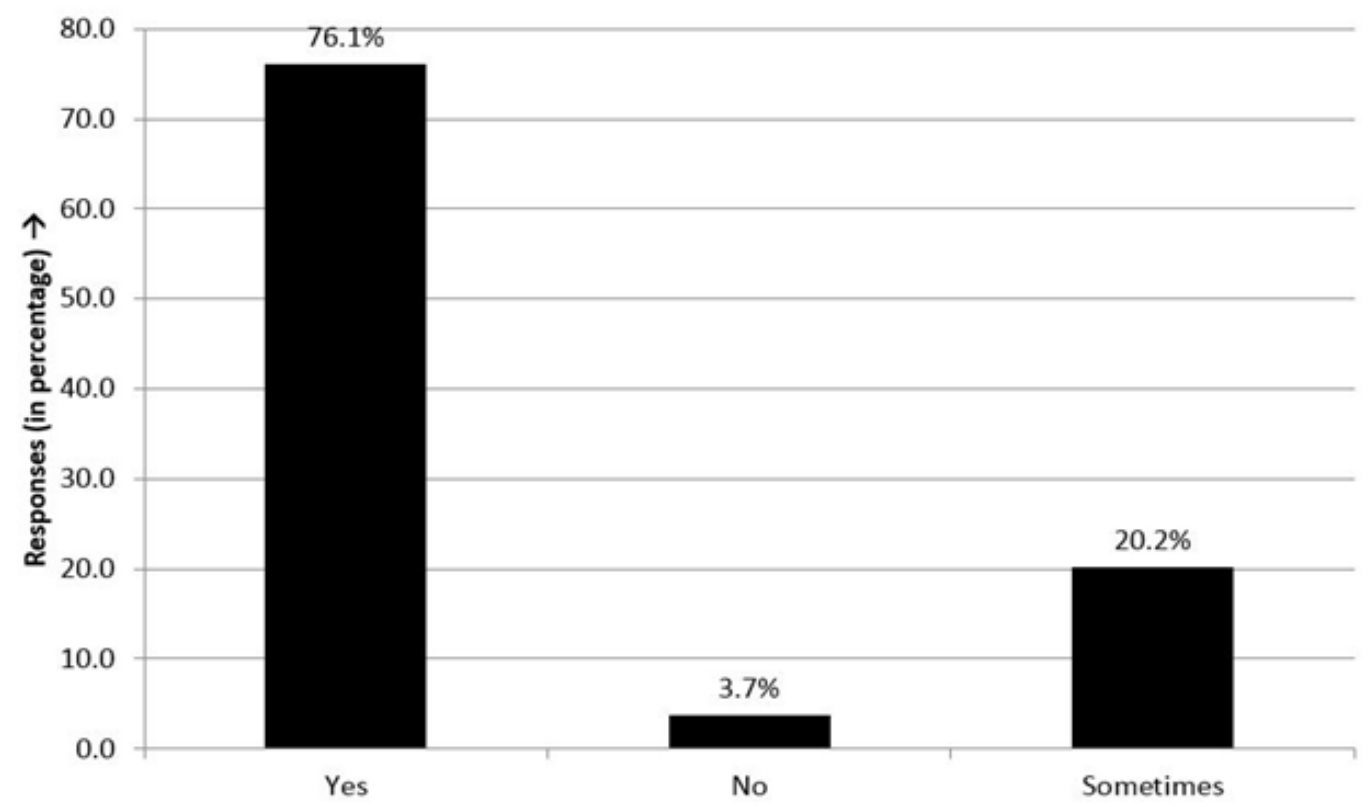

Fig 1. Do you feel engaged in online classes

\section{IS ONLINE LEARNING PROGRAM WORKING FOR YOUR CHILD?}

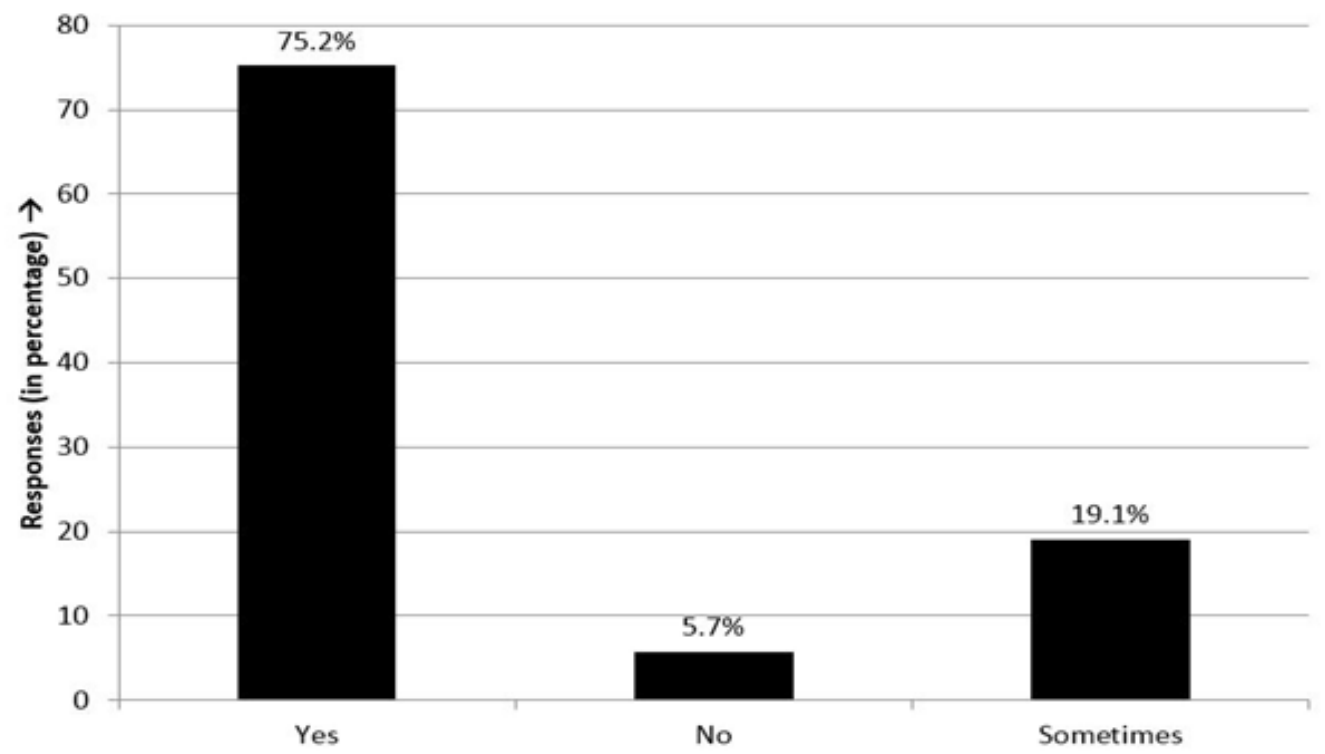

Fig 2. Is online learning program working for your child 


\section{WHAT SHOULD BE THE DURATION OF ONLINE CLASSES ACCORDING TO YOU?}

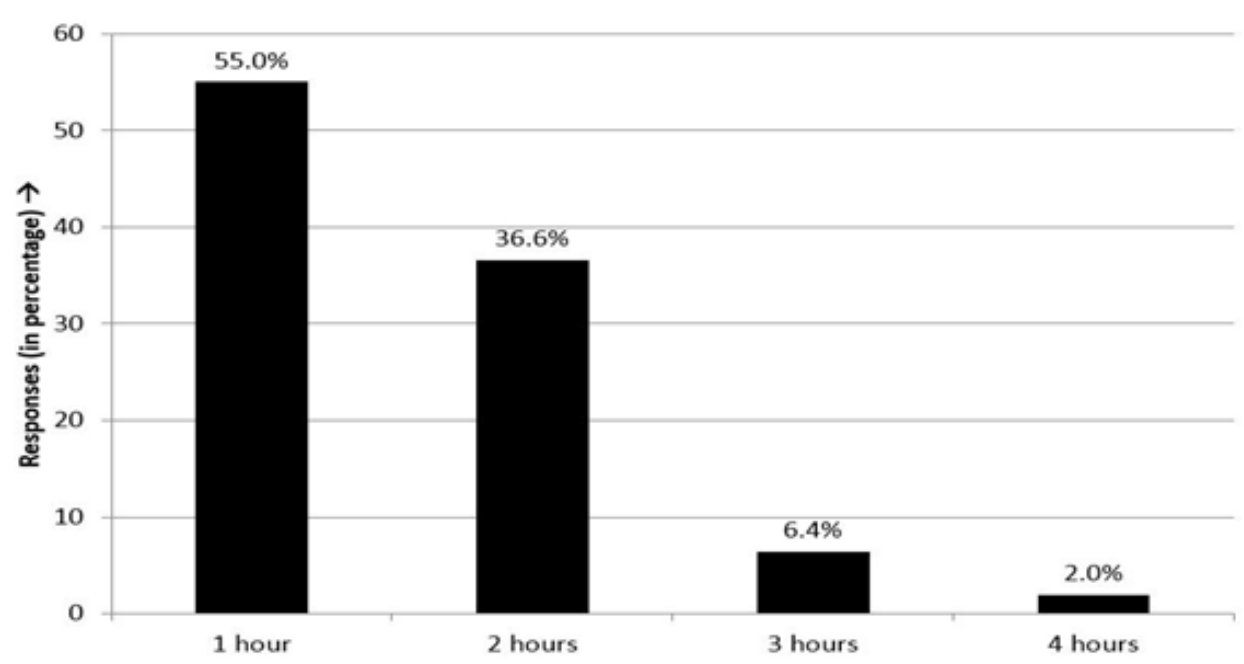

Fig 3. What should be the duration of online classes according to you?

\section{WHAT ARE THE ATTRIBUTES OF ONLINE CLASSES THAT ENHANCE THE TEACHING LEARNING PROCESS?}

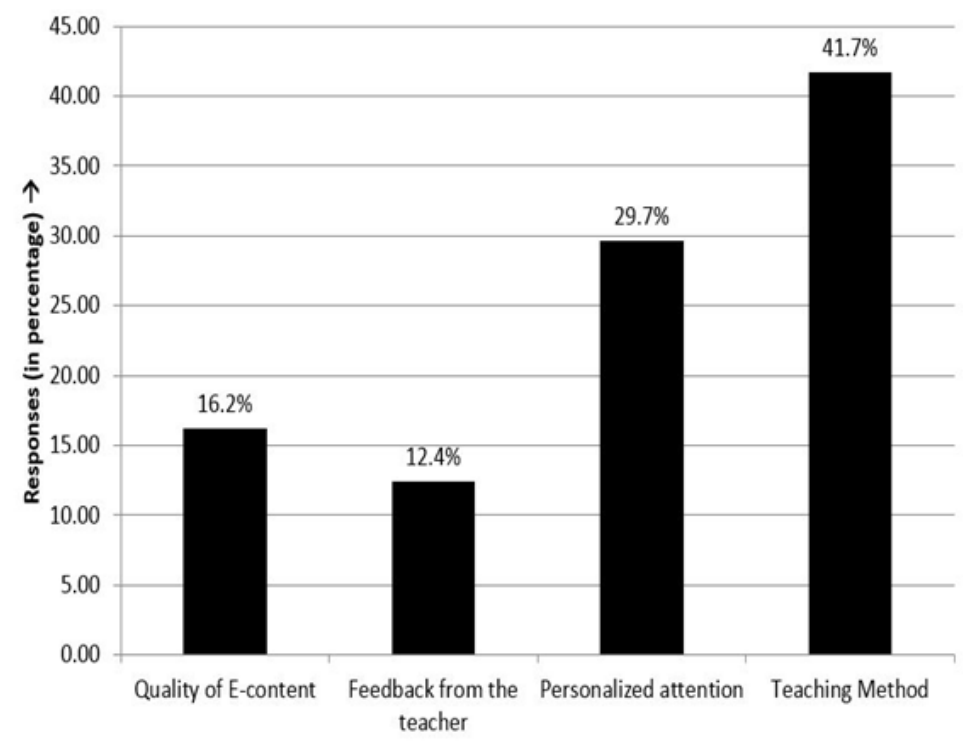

Fig 4. What are the attributes of online classes that enhance the teaching-learning process? 


\section{HAS ONLINE TEACHING ADVERSELY AFFECTED YOUR WARD'S HEALTH?}

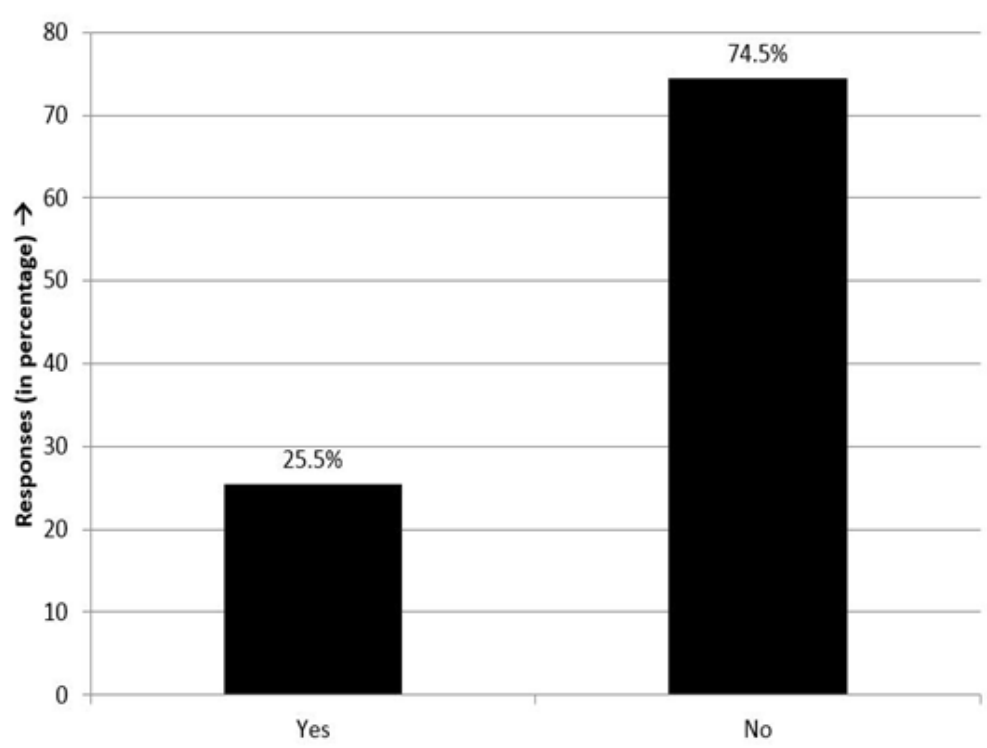

Fig 5. Has online teaching adversely affected your ward's health?

\section{DO YOU THINK THAT ONLINE CLASSES IS THE NEED OF THE HOUR?}

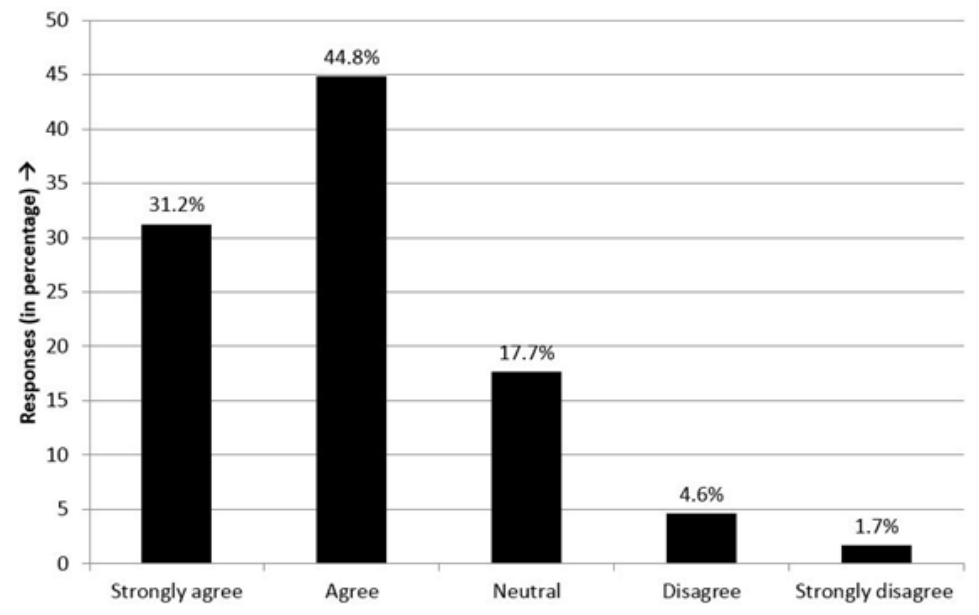

Fig 6. Do you think that online classes is the need of the hour? 


\section{Results from the survey for classes III to V}

More than $81 \%$ of the parents feel connected with the online classes and $78.4 \%$ believe that online learning program is working for their children. Also, $72 \%$ of the respondents think that online classes should have the duration of two to three hours per day which is at least $50 \%$ less than the time spent in the regular school. Nearly $40 \%$ of the parents think that teaching methodology is the most important factor that can enhance the teaching and learning process, followed by personalised attention (26\%) and quality of e-content. Face to face learning provides benefits from learning by doing, being able to bodily and sensorially experience a whole setting for motivating and encouraging the students since in-person interaction and learning from peers can not happen in online teaching. Thus, interaction between students and teachers is far more effective as it leads to cultivating personal relations. Technical issues (56.2\%) are the most important source of distraction during online classes. So far as the health effects of online teaching are concerned, more than $60 \%$ of the parents do not think that there have been any adverse impacts. This number is lower than the previous group, illustrating that in early adolescence years, children start using digital platforms for more than the time approved by parents. However, more than $75 \%$ of the parents either agree or strongly agree with the need of the online classes, roughly the same number as the previous group.

\section{DOES YOUR CHILD FEEL CONNECTED/ ENGAGED IN ONLINE CLASSES?}

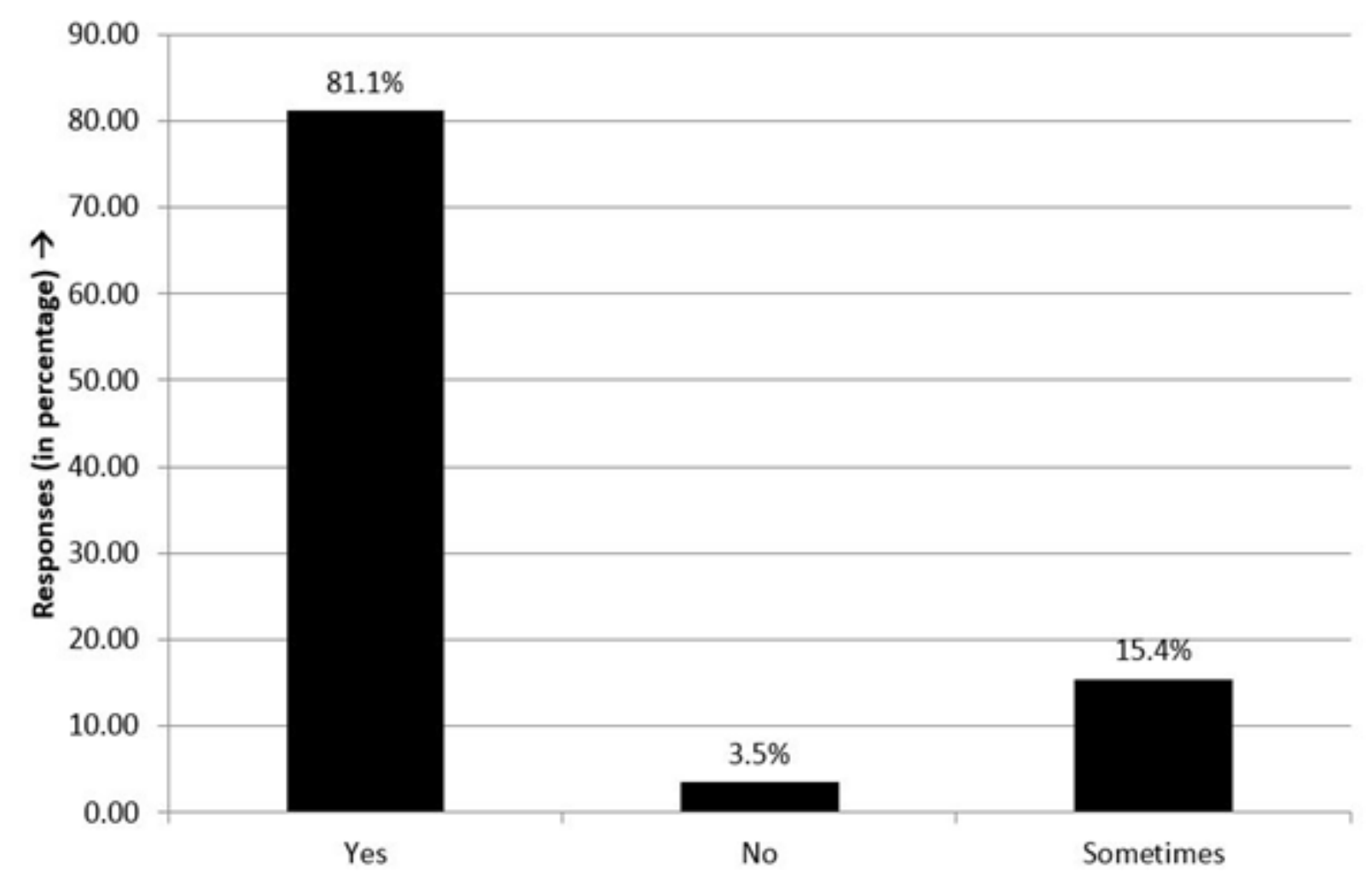

Fig 7. Does your child feel engaged with the online classes? 


\section{IS ONLINE LEARNING PROGRAM WORKING FOR YOUR CHILD?}

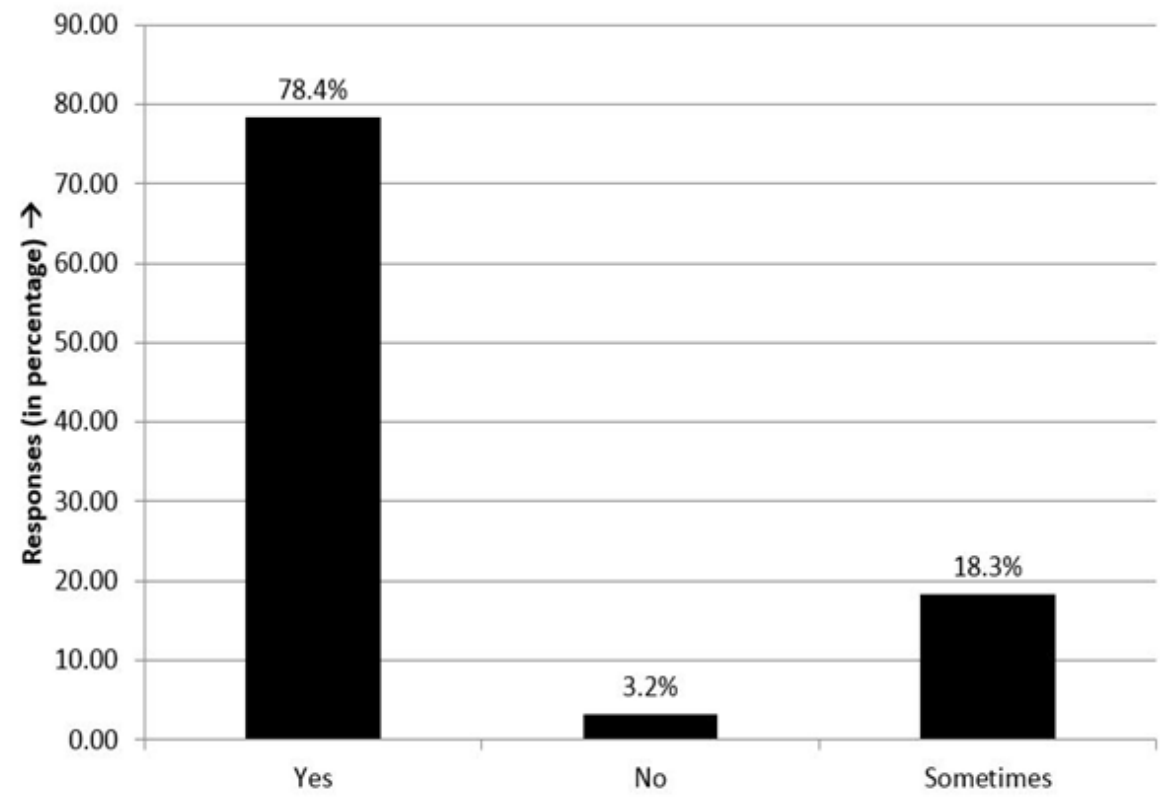

Fig 8. Is online learning program working for your child?

\section{WHAT SHOULD BE THE DURATION OF ONLINE CLASSES ACCORDING TO YOU?}

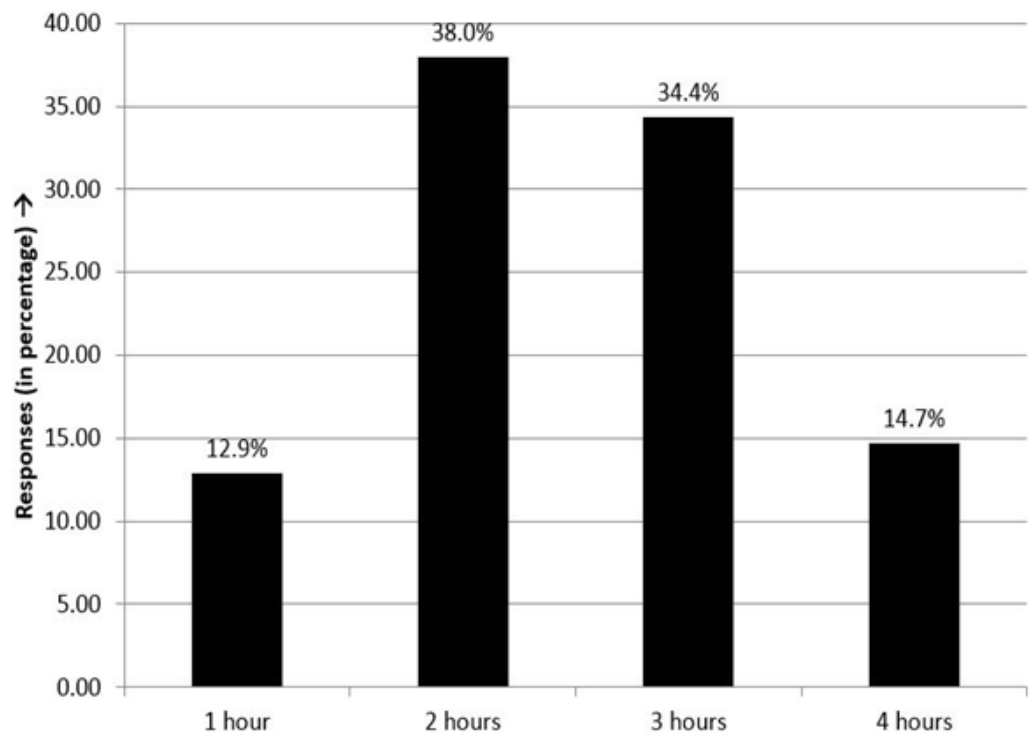

Fig 9. What should be the duration of online classes according to you? 


\section{WHAT ARE THE ATTRIBUTES OF ONLINE CLASSES THAT ENHANCE THE TEACHING LEARNING PROCESS?}

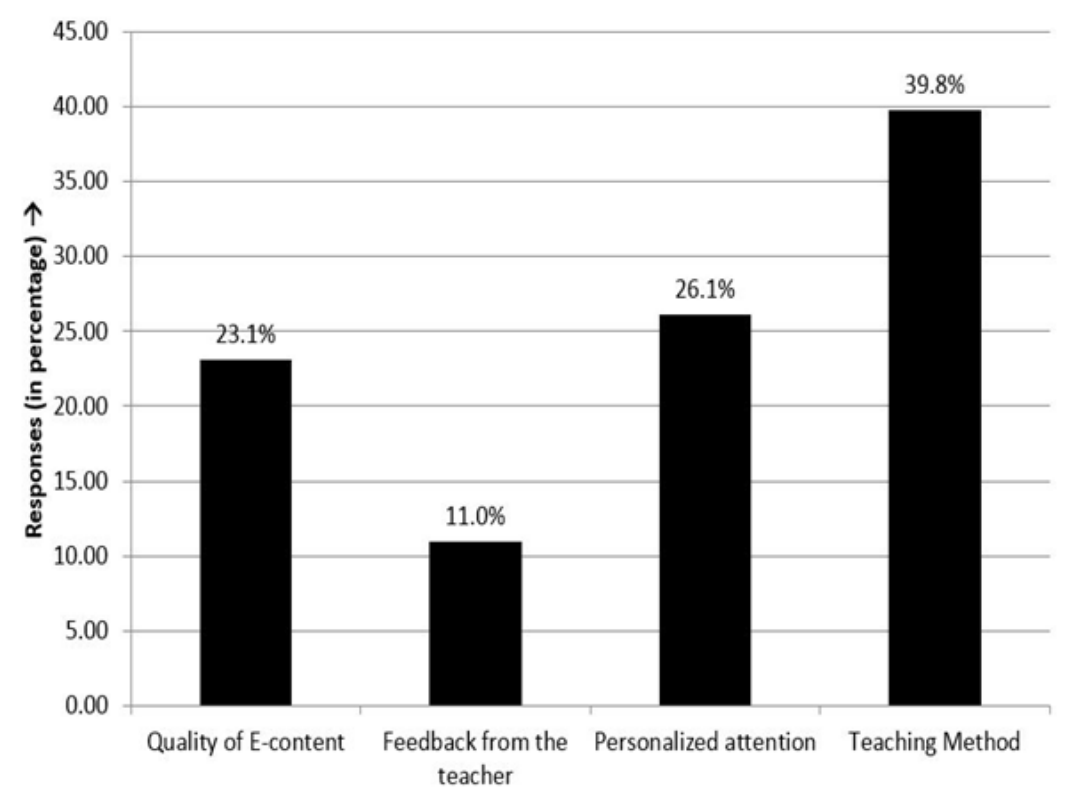

Fig 10. What are the attributes of online classes that enhance the teaching-learning process?

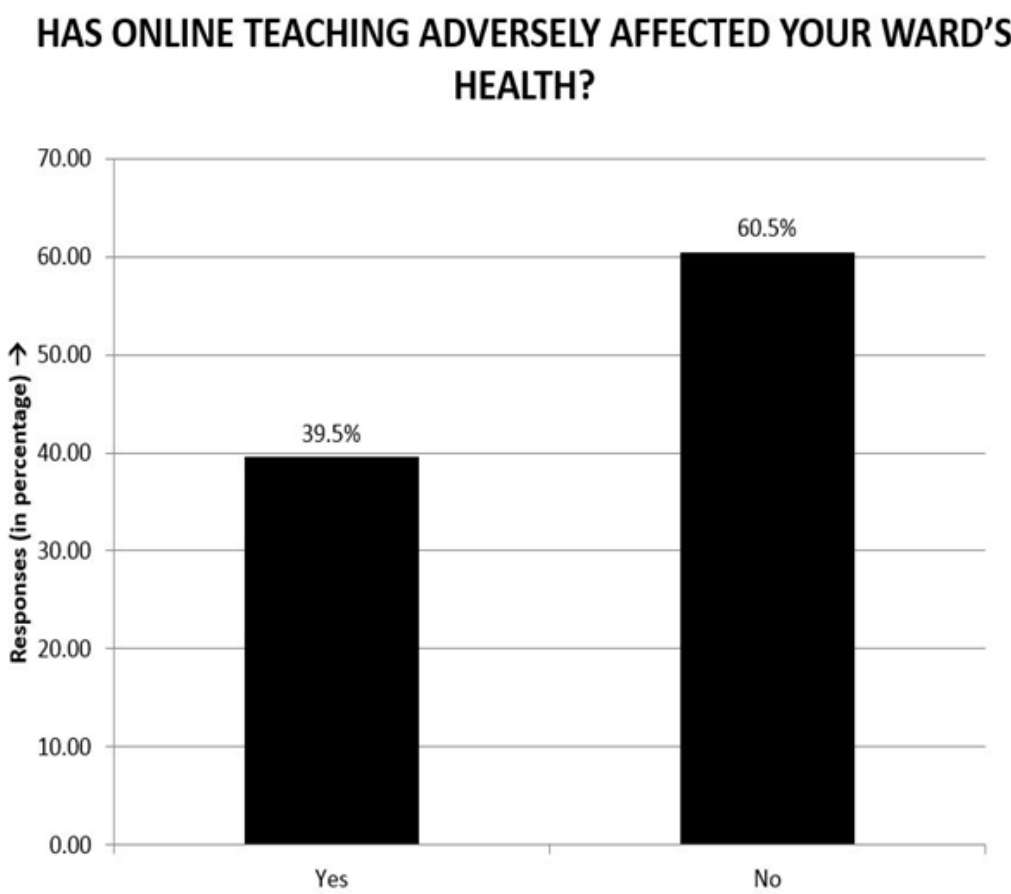

Fig 11. Has online teaching adversely affected your ward's health? 


\section{DO YOU THINK THAT ONLINE CLASSES IS THE NEED OF THE HOUR?}

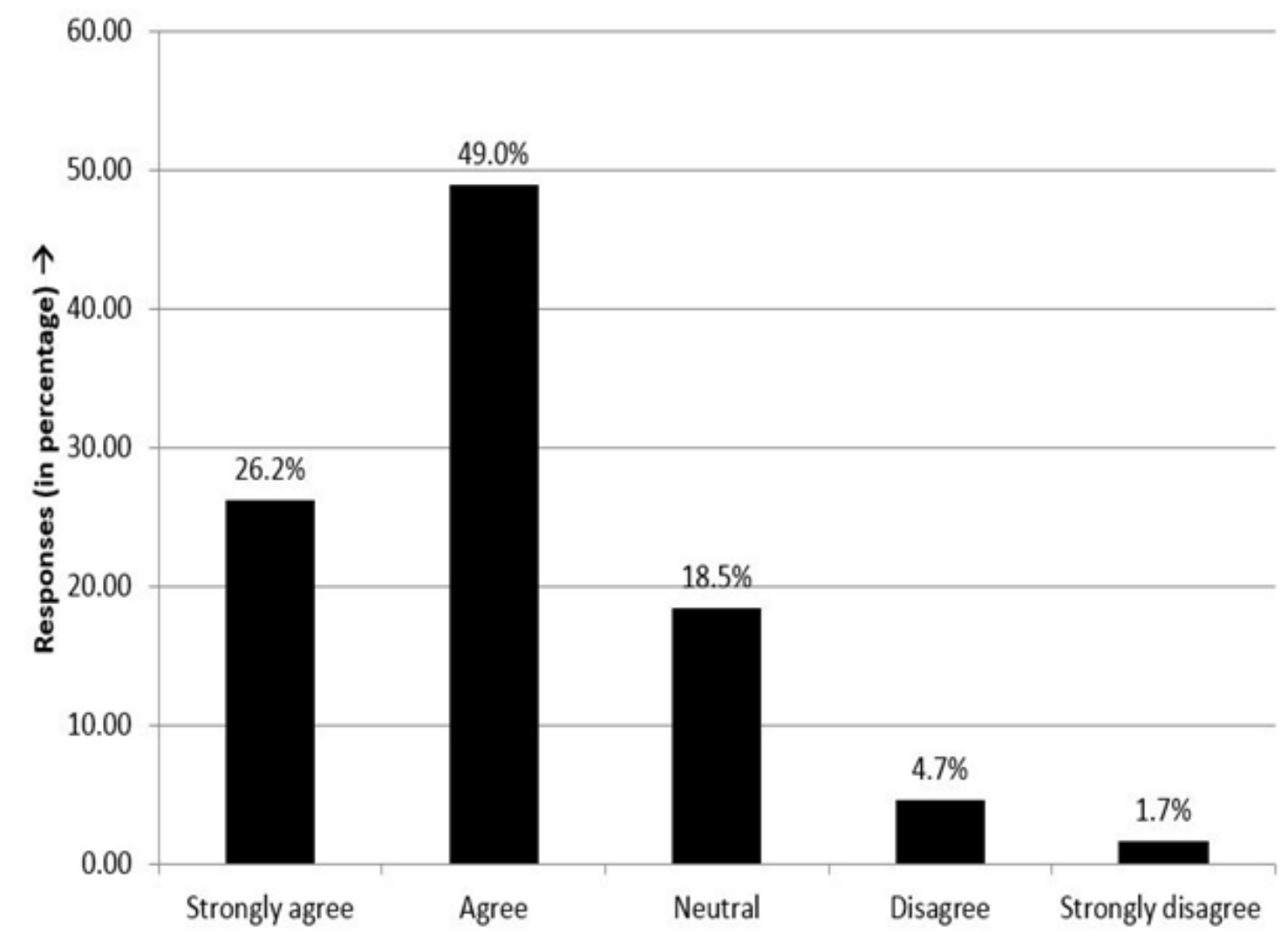

Fig 12. Do you think that online classes is the need of the hour?

\section{Discussion}

The Covid-19 pandemic initiated an extensive, sudden and dramatic digital transformation in the society. It forced the schools and the families to take an extraordinary digital leap in our everyday life and practices. Suddenly an entire generation of young parents had to start managing and mastering digital tools to let their children participate in online education (19). What years of schools' encouragement to the students and teachers to take to digital platforms couldn't achieve in a country like India, was achieved at a much faster pace during the pandemic. A study of perceptions of primary school teachers of Indonesia also indicates that countries with great geographic spread and vastly different socio-economic backgrounds takes a humungous effort to succeed in online education ${ }^{(19)}$. Even if digitisation of education has been around for many years, schools, teachers and parents have been poorly prepared for acting as change agents in this educational revolution ${ }^{(20)}$, but now with pedagogy shifting from monotonous classes in a lecture method to interactive online tools such as google classrooms, Microsoft teams, zoom etc, online education is being gradually accepted. Reading and writing assignments are getting done using various learning apps for which parents support is needed to assist the young children. All this has happened with such a fast pace that 
families had to learn a variety of skills and competencies besides acquiring resources. Parents, teachers and students alike had to learn integrating digital tools into learning in meaningful ways to get benefit from them ${ }^{(21)}$. A study of Spanish schools ${ }^{(22)}$ reveals that parents and teachers hold a set of beliefs about the digital media use for teaching. It shows that parents display more positive attitude for online teaching where the parent-school communication through emails is a regular feature. Without a doubt, the future of education lies in the development of a holistic model that takes into account digital platforms for teaching and learning ${ }^{(23)}$. From initial inertia and resistance towards digital education to becoming hands-on with online education, parents have come a long way in changing their attitudes, values and mindsets needed for future ${ }^{(24)}$.

\section{Limitations and gaps}

The findings from this research have shown that parental engagement with young students is of great significance for online teaching since they assist their children in taking online classes at home. It has also corroborated that longer stretch of online classes during the school-day is not welcomed by the parents and they think that there is a vast difference between online teaching and offline activities. Besides the teachers' role in such a teaching process, there is also an equally important role of the parents. However, this study was limited only to ten schools in Delhi-NCR region which primarily catered to students belonging to lower-middle to upper-middle classes of the society. The number of students belonging to economically weaker sections was only $25 \%$ of the total school population which primarily suffers from lack of technological savvy as well as tools. Further research is needed to better understand the role, opinion and perception of parents from across the Indian society as far as online teaching is concerned, which is here to stay for an uncertain duration of time in the future.

\section{Conclusion}

An effective online engagement between school, students and parents can work only with the confluence of relationships among them. School and parents have to work together for building a learning environment for their children, particularly when they are dependent on them for resources and learning ambience. Schools should share a part of this responsibility for educating parents on the use of digital tools since young children depend on their parents for facilitating online learning for them. Virtual classes are here to stay, much longer than the school authorities and parents had ever anticipated. Teachers got adequate opportunities for training themselves on the use of virtual platforms but it's time we start looking at the issue from parents' perspective. When parents have to fill children's time in a closed space of the home, without contact with peers and teachers, it generates many tensions and conflicts, making everyday life difficult. Parents are unable to cope with the tasks suddenly entrusted to them for academic support at home. Therefore, an extremely important task for future is to prepare the parents for emotional and technological skills to face future potential events. It's time the government also noticed this to take steps for encouraging them to learn.

\section{Appendix A}

\section{Questionnaire for parent survey}

\begin{tabular}{ll}
\hline Q. No. & NUR - II \\
\hline 1 & Does your child feel connected/ engaged in online classes? \\
2 & Is online learning program working for your child? \\
3 & What should be the duration of online classes according to you? \\
4 & What are the attributes of online classes that enhance the teaching learning process? \\
5 & Has online teaching adversely affected your ward's health? \\
6 & Do you think that online classes are the need of the hour? \\
\hline
\end{tabular}




\section{Appendix B}

\section{Questionnaire for parent survey}

\begin{tabular}{ll}
\hline Q. No. & III - V \\
\hline 1 & Does your child feel connected/ engaged in online classes? \\
2 & Is online learning program working for your child? \\
3 & What should be the duration of online classes according to you? \\
4 & What are the attributes of online classes that enhance the teaching learning process? \\
5 & Has online teaching adversely affected your ward's health? \\
6 & Do you think that online classes are the need of the hour? \\
\hline
\end{tabular}

\section{References}

1) Dai D, Lin G. Online Home Study Plan for Postponed 2020 Spring Semester during the COVID-19 Epidemic: A Case Study of Tangquan Middle School in Nanjing, Jiangsu Province, China. SSRN Electronic Journal. 2020;4:543-547. Available from: https: //dx.doi.org/10.2139/ssrn.3555539. doi:10.2139/ssrn.3555539.

2) Rajhans V, Memon U, Patil V, Goyal A. Impact of COVID-19 on academic activities and way forward in Indian Optometry. Journal of Optometry. 2020;13(4):216-226. Available from: https://dx.doi.org/10.1016/j.optom.2020.06.002. doi:10.1016/j.optom.2020.06.002.

3) Parczewska T. 2020.

4) Murray E, McFarland-Piazza L, Harrison LJ. Changing patterns of parent-teacher communication and parent involvement from preschool to school. Early Child Development and Care. 2015;185(7):1031-1052. Available from: https://dx.doi.org/10.1080/03004430. 2014.975223. doi:10.1080/03004430.2014.975223.

5) Song Z, Wang C, Bergmann L. China’s prefectural digital divide: Spatial analysis and multivariate determinants of ICT diffusion. International Journal of Information Management. 2020;52:102072-102072. Available from: https://dx.doi.org/10.1016/j.ijinfomgt.2020. 102072. doi:10.1016/j.ijinfomgt.2020.102072.

6) Gray JA, Diloreto M. The Effects of Student Engagement, Student Satisfaction, and Perceived Learning in Online Learning Environments. International Journal of Educational Leadership Preparation. 2016;(1):11-11.

7) Zhu S, Yang HH, Macaleod J, Shi Y, Wu D. .

8) Soykan E. Views of students', teachers' and parents' on the tablet computer usage in education. Cypriot Journal of Educational Sciences. 2015;10(3):228-228. Available from: https://dx.doi.org/10.18844/cjes.v1i1.68. doi:10.18844/cjes.v1i1.68.

9) Hale L, Troxel W, Buysse DJ. Sleep Health: An Opportunity for Public Health to Address Health Equity. Annual Review of Public Health. 2020;41(1):81-99. Available from: https://dx.doi.org/10.1146/annurev-publhealth-040119-094412. doi:10.1146/annurev-publhealth040119-094412.

10) Brom C, Lukavský J, Greger D, Hannemann T, Straková J, Švaříček R. 2020.

11) Data from: COVID-19 Educational Disruption and Response. UNESCO. 2020.

12) Viner R, Bonell OT, Melendez-Torres C, Ward GJ, Hudson JL, Waddington L, et al. Susceptibility to and transmission of COVID-19 amongst children and adolescents compared with adults: a systematic review and meta-analysis. MedRxiv Posted. 2020.

13) Simonson M, Zvacek SM, Smaldino S. Teaching and Learning at a Distance: Foundations of Distance Education (7th Edn. Charlotte, NC. Information Age Publishing. 2019.

14) Valcke M, Wever BD, Keer HV, Schellens T. Long-term study of safe Internet use of young children. Computers \& Education. 2011;57(1):1292-1305. Available from: https://dx.doi.org/10.1016/j.compedu.2011.01.010. doi:10.1016/j.compedu.2011.01.010.

15) Garmendia M, Casado MA, Martínez G, Garitaonandia C. 2013.

16) Connell SL, Lauricella AR, Wartella E. Parental Co-Use of Media Technology with their Young Children in the USA. Journal of Children and Media. 2015;9(1):5-21. Available from: https://dx.doi.org/10.1080/17482798.2015.997440. doi:10.1080/17482798.2015.997440.

17) Vial G. Understanding digital transformation: A review and a research agenda. The Journal of Strategic Information Systems. 2019.

18) Papagiannidis S, Harris J, Morton D. WHO led the digital transformation of your company? A reflection of IT related challenges during the pandemic. International Journal of Information Management. 2020;55:102166-102166. Available from: https://dx.doi.org/10.1016/j. ijinfomgt.2020.102166. doi:10.1016/j.ijinfomgt.2020.102166.

19) Rasmitadila R, Aliyyah RR, Rachmadtullah R, Samsudin A, Syaodih E, Nurtanto M, et al. The Perceptions of Primary School Teachers of Online Learning during the COVID-19 Pandemic Period: A Case Study in Indonesia. Journal of Ethnic and Cultural Studies. 2020;7(2):90-90. Available from: https://dx.doi.org/10.29333/ejecs/388. doi:10.29333/ejecs/388.

20) Bordalba MM, Bochaca JG. Digital media for family-school communication? Parents' and teachers' beliefs. Computers \& Education. 2019;132:44-62. Available from: https://dx.doi.org/10.1016/j.compedu.2019.01.006. doi:10.1016/j.compedu.2019.01.006.

21) Kapasia N, Paul P, Roy A, Saha J, Zaveri A, Mallick R, et al. Impact of lockdown on learning status of undergraduate and postgraduate students during COVID-19 pandemic in West Bengal, India. Children and Youth Services Review. 2020;116:105194-105194. Available 
from: https://dx.doi.org/10.1016/j.childyouth.2020.105194. doi:10.1016/j.childyouth.2020.105194.

22) Saghafi MR, Franz J, Crowther P. A Holistic Model for Blended Learning. Journal of Interactive Learning Research. 2014;25(4):531-549.

23) Northey G, Bucic T, Chylinski M, Govind R. Increasing Student Engagement Using Asynchronous Learning. Journal of Marketing Education. 2015;37(3):171-180. Available from: https://dx.doi.org/10.1177/0273475315589814. doi:10.1177/0273475315589814.

24) Mariën I, Prodnik JA. Digital inclusion and user (dis)empowerment: a critical perspective. info. 2014;16(6):35-47. Available from: https://dx.doi.org/10.1108/info-07-2014-0030. doi:10.1108/info-07-2014-0030. 